\title{
Mucous cell responses in gill and skin of brown trout Salmo trutta fario in acidic, aluminium- containing stream water
}

\author{
K. Ledy ${ }^{1}$, L. Giambérini ${ }^{1, *}$, J. C. Pihan ${ }^{2}$ \\ ${ }^{1}$ Laboratoire Ecotoxicité et Santé Environnementale, CNRS FRE 2635, and ${ }^{2}$ Laboratoire Biodiversité et Fonctionnement des \\ Ecosystèmes, Université de Metz, Campus Bridoux, Rue du Général Délestraint, 57070 Metz, France
}

\begin{abstract}
Morphometric examination was carried out on the gills and skin of wild and caged hatchery brown trout Salmo trutta fario in an acidic (pH 4.9 to 5.4; Al 203 to $250 \mu \mathrm{g} \mathrm{l}^{-1}$ ) and in a nonacidic (pH 6.7 to $7.0 ; \mathrm{Al} 27$ to $67 \mu \mathrm{g} \mathrm{l^{-1 }}$ ) stream in the Vosges Mountains (NE France) to assess the sublethal effects of acidic water on the mucous cell response. The caged fish were randomly collected after 2, 4, 7 and $11 \mathrm{~d}$ and the wild fish were obtained by electrofishing. After $2 \mathrm{~d}$, a reduction of both mucous cell (MC) number and size was observed in the gills of fish held in the acidic stream, suggesting a massive mucus discharge. Hyperplasia and hypertrophy of cells immediately followed this mucus secretion. In the same fish population, skin examination showed a slight and delayed decrease of MC number but a significant increase of cell size. The number of mucous cells of gills and skin was similar in both wild trout populations, whereas a significant MC hypertrophy was observed in the wild fish of the acidic stream. The present field experiment indicates that caged fish could be useful as early indicators of acidification. In addition, the examination of wild populations suggested the occurrence of adaptive mechanisms, information that might be of importance in the context of river recovery programs.
\end{abstract}

KEY WORDS: Acidification · Aluminium $\cdot$ Gill $\cdot$ Skin $\cdot$ Mucous cells $\cdot$ Salmo trutta fario Resale or republication not permitted without written consent of the publisher

\section{INTRODUCTION}

Acidic atmospheric depositions have been responsible for freshwater acidification in North America and in some European countries during the last 3 decades (Probst et al. 1992, Guérold et al. 1997). The consequences of this progressive acidification include the decrease and/or loss of vertebrate and invertebrate populations (Hesthagen et al. 1999, Guérold et al. 2000). Despite recent reductions of sulphur and nitrogen emissions, acidification of freshwater remains a serious environmental problem. In France, and particularly in the Vosges Mountains, numerous streams remain acidic and are characterized by very low alkalinities with low $\mathrm{Ca}$ and elevated $\mathrm{Al}$ concentrations.

The main impacts of acidic water on fish involve disturbance of ion regulation and gas exchange, pro- cesses partly performed by the gill (Verbost et al. 1995, Perry 1997, Claiborne 1998). The branchial epithelium is composed of several cell types, including pavement cells, chloride cells and mucous cells (MC) (Laurent 1984, Olson 1996).

The skin is a physiologically active border tissue which consists of several cell types, including MC. Like the gills, the skin is in immediate contact with the environment and shows a direct response to different environmental stressors (Zuchelkowski et al. 1986, Iger et al. 1994b).

Exposure to acidic water and associated stressors induces a variety of rapid cellular modifications in gill and skin epithelia (Karlsson-Norrgren et al. 1986, Goossenaerts et al. 1988). Among these, both changes in chemical composition of the mucus and stimulated mucus production have been noted (Iger et al. 1994b, Berntssen et al. 1997). 


\begin{tabular}{|c|c|c|c|c|}
\hline 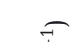 & $\pi$ & 6 & & \\
\hline U & 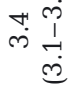 & 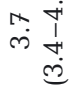 & $\stackrel{-}{-}$ & $\begin{array}{ll}\infty & 1 \\
0 & 1 \\
0 & 0 \\
0 & 0\end{array}$ \\
\hline & $\mathbb{\pi}$ & $\begin{array}{l}0 \\
\stackrel{0}{1}\end{array}$ & & $\underset{F}{\overparen{H}}$ \\
\hline 总 & $\begin{array}{cc}0 & 0 \\
0 & 1 \\
0 & 0 \\
0 & 0\end{array}$ & 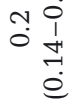 & $\stackrel{N}{0}$ & $\begin{array}{cc}-1 & 0 \\
0 & 1 \\
0 & 0 \\
0 & 0\end{array}$ \\
\hline & $\pi$ & $\overline{\vec{m}}$ & F & $\stackrel{\mathbb{X}}{\sim}$ \\
\hline 滪 & 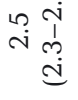 & 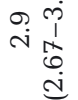 & 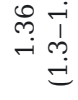 & 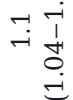 \\
\hline + & $\neg$ & $m \stackrel{\substack{m \\
m}}{-}$ & లె & $\begin{array}{l}\text { స̃ } \\
\text { N }\end{array}$ \\
\hline$\Sigma$ g & $-i$ & $-\underset{N}{-i}$ & $\begin{array}{ll}0 \\
0 \\
0\end{array}$ & $\stackrel{0}{0}$ \\
\hline 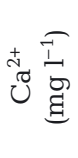 & 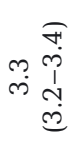 & 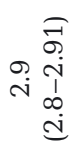 & $\stackrel{\leftrightarrow}{0}$ & $\begin{array}{cc} & 5 \\
& 0 \\
0 \\
0 & 0 \\
0 & 1 \\
0 & 0 \\
1 & 0 \\
0 & 0\end{array}$ \\
\hline$\widetilde{F}$ & & $\stackrel{5}{?}$ & $\widetilde{x}$ & $\overline{\vec{m}}$ \\
\hline 蒫 & $\ddot{0}$ & $\begin{array}{rl}-1 & 0 \\
0 & 1 \\
0 & 0 \\
0 & 0 \\
0\end{array}$ & 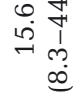 & 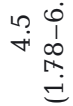 \\
\hline 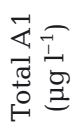 & 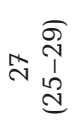 & 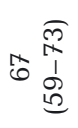 & 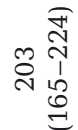 & 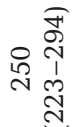 \\
\hline 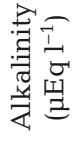 & 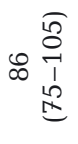 & 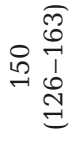 & 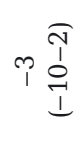 & $\dashv \underset{1}{\stackrel{F}{I}}$ \\
\hline 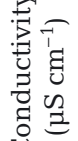 & 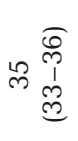 & 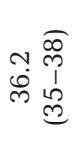 & 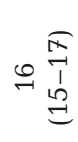 & $\stackrel{m}{\rightarrow}$ \\
\hline 茎 & 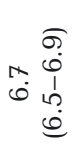 & 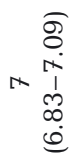 & 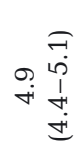 & 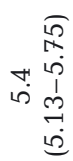 \\
\hline 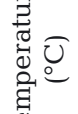 & 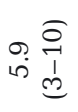 & $\stackrel{\sim}{\sim}$ & 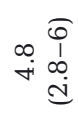 & $\stackrel{\nearrow}{\leftrightarrows}$ \\
\hline & 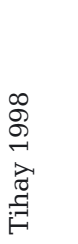 & 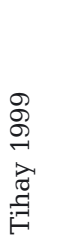 & 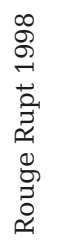 & 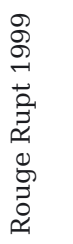 \\
\hline
\end{tabular}

The objective of this study was to assess and compare, under natural conditions, the structural responses of $\mathrm{MC}$ in gill and skin epithelia, both in transferred and wild fishes exposed to acidic water. The transfer experiment was carried out over an $11 \mathrm{~d}$ period in 2 streams showing different degrees of acidity. The adult wild brown trout which occurred in the acidic stream were the result of annual restocking with juvenile stages. This histological investigation was part of a comprehensive project examining the effects of water acidification on fish physiology and morphological responses.

\section{MATERIALS AND METHODS}

Study area and water chemistry. The studies were performed in the Vosges Mountains (NE France) in 1998 and 1999. Based on previous extensive surveys (Guérold et al. 1997), an acidic (Rouge Rupt) and a nonacidic stream (Tihay), both located upstream of anthropogenic activities, were chosen for use in the study.

Water samples for physico-chemical analysis were collected in polyethylene bottles at each site and for each exposure time. Samples were analyzed for acidic neutralizing capacity (ANC) using the Gran titration method and for $\mathrm{Cl}^{-}$by ion chromatography (Dionex apparatus). Major cations $\left(\mathrm{Ca}^{2+}, \mathrm{Mg}^{2+}, \mathrm{Na}^{+}, \mathrm{K}^{+}\right)$and total $\mathrm{Al}$ were measured by atomic absorption spectrophotometry after acidification with $\mathrm{HNO}_{3}$. Temperature and $\mathrm{pH}$ were measured in situ and in the laboratory using a specific glass electrode for low ionic solutions. Conductivity was measured at $25^{\circ} \mathrm{C}$. The mean values of some physico-chemical parameters of the 2 streams are compiled in Table 1.

Fish and experimental protocol. Adult brown trout Salmo trutta fario (length 250 to $330 \mathrm{~mm}$ ) were obtained from a fish hatchery and were transferred in June 1999 to Tihay and Rouge Rupt. During the experiment, fish were placed underwater in perforated 351 plastic cages. On the day of transfer, 5 fish were not placed into the streams, but transported to the laboratory and immediately dissected in order to assess the initial levels of tested parameters. After 2, 4, 7 and $11 \mathrm{~d}$, trout ( $\mathrm{n}=5$ to 7 ) were randomly removed from each different cage in the streams, ensuring that the numbers of fish in each cage remained about the same. Fish were transported to the laboratory under refrigeration within 15 min of collection.

Local brown trout populations (length 135 to $260 \mathrm{~mm}$ ) were caught by electrofishing in these 2 streams in July 1998, killed by a blow to the head, and dissected.

Histology and morphometry. The second gill arch from the left side of each fish was excised and then sectioned longitudinally, parallel to the filaments and perpendicular to the lamellae. Slides were stained with 
Alcian blue at $\mathrm{pH} 2.5$ to highlight acidic mucosubstances in mucocyte vacuoles.

Gill MC number and size were determined with a light microscope at $250 \times$ for each individual by examining the following: 3 regions of the filament (base, middle and apex), 4 filaments per section, 3 sections separated by at least 4 interval sections. Each region examined consisted of 10 adjoining lamellae and their associated interlamellar spaces on each side of the filament. This represented a total of 36 measurements per individual. Since no significant differences were observed between the 3 regions, only the total numbers of $\mathrm{MC}$ are presented. Microscopic images were captured with an image analysis system (Analysis pro 3.0, Olympus) using a color tri charged coupled device (CCD) video camera. The size of MC and the surface area of tissue in each field was automatically evaluated, and $\mathrm{MC}$ numbers were expressed per $\mathrm{mm}^{2}$ of gill tissue.
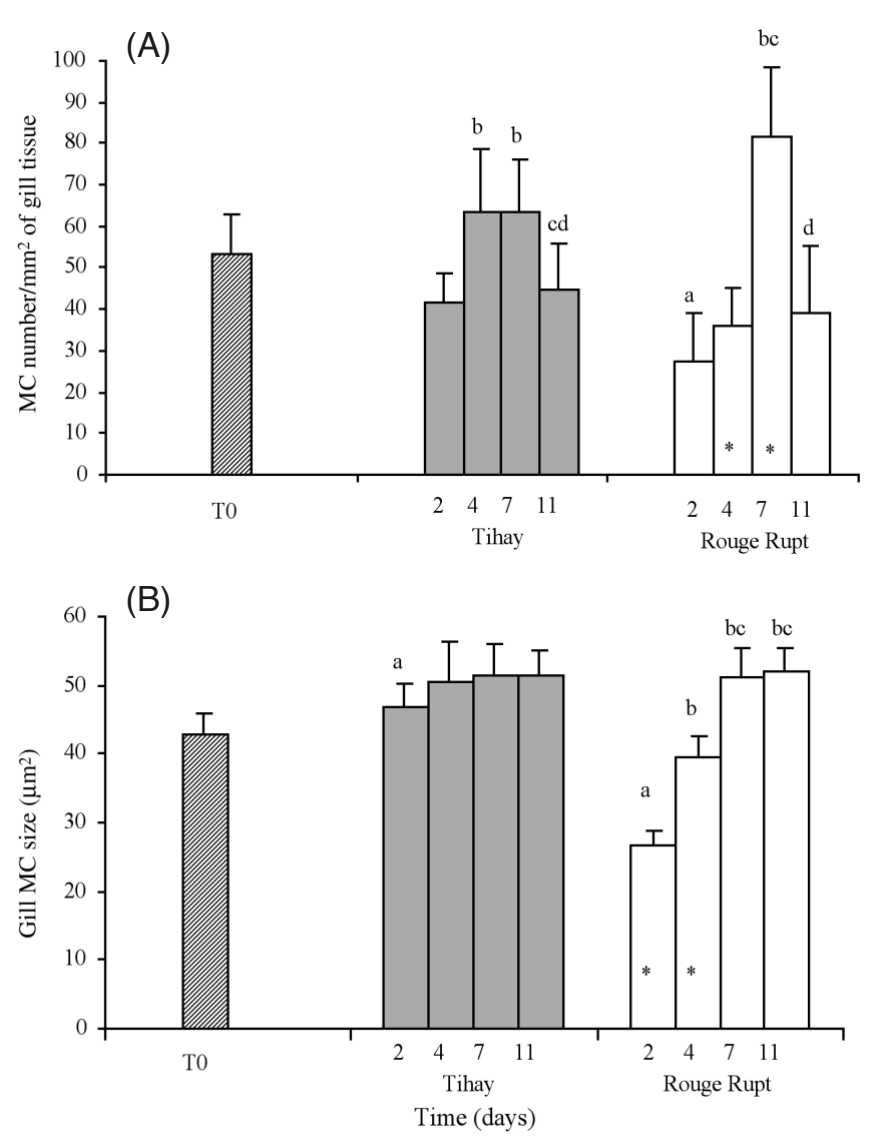

Fig. 1. Salmo trutta fario. (A) Mean number \pm SD of mucous cells (MC) per $\mathrm{mm}^{2}$ of gill tissue. (B) Mean size $\pm \mathrm{SD}$ of gill MC $\left(\mu \mathrm{m}^{2}\right)$. Trout were transferred into non-acidic water (Tihay) and into acidic water (Rouge Rupt). Data with letters and/or an asterisk are significantly different $(p<0.05)$ from: (a) time zero (T0), (b) $2 \mathrm{~d}$ of exposure, (c) $4 \mathrm{~d}$ of exposure, (d) $7 \mathrm{~d}$ of exposure, and (*) between the 2 streams for the same days of exposure
A small piece of skin tissue was dissected from the ventral side, near the head (between the pectoral fins), and treated and stained in the same way as gill tissues. Microscopic images of skin at $400 \times$ were captured with the same image analysis system, and the number and size of the mucocytes were recorded. The surface of skin tissue was assessed in each field and the number of cells expressed per $\mathrm{mm}^{2}$ of tissue. Epidermis measurements were determined in 4 fields (ranging from 17000 to $24500 \mathrm{\mu m}^{2}$ ) per section, using 5 sections separated at least by 4 interval sections, and thus totaled 20 measurements per individual.

Statistical analysis. Comparisons between the different experimental groups of transferred fish were made using 2-way analysis of variance (ANOVA) to check the effect of exposure to acidified water (i.e. exposure time and acidification degree) on mucus production. The differences between means were significant at the $p<0.05$ level using a Duncan's multiple range comparison test performed with Statistica software (StatSoft). Differences between the local fish populations were assessed by ANOVA.

\section{RESULTS}

\section{MC of transferred fish}

The results of an initial transfer study carried out in 1998 using a shorter exposure period were confirmed in the present work. Exposure time $(p<0.001)$ and the interaction of tested parameters $(p<0.002)$ had a statistically significant effect on gill $\mathrm{MC}$ number. On the day of fish transfer, $53 \pm 10$ cells $\mathrm{mm}^{2}$ (Fig. 1A) were recorded in the gill. Over the exposure period, the number of MC did not show any significant variation in fish transferred to non-acidic water compared to the initial level. The number of MC increased after $4 \mathrm{~d}$, stayed high, and then declined by the end of the exposure period to the level observed on Day 2. Following the direct transfer into the acidic stream, the number of mucocytes greatly decreased in the gill, suggesting stimulated mucus secretion. Numerical density of mucocytes also tended to be lower $(\mathrm{p}<$ 0.09) than that observed in the non-acidic stream. The hyperplasia of $\mathrm{MC}$ recorded after $7 \mathrm{~d}$ following transfer into acidic water was followed by a reduction in cell number.

The tested parameters and their interactions were significant determinants of gill MC size. Following direct transfer to non-acidic water, $\mathrm{MC}$ size increased and remained constant throughout the experimental period (Fig. 1B). In contrast, MC size decreased in the gills of fish held in the acidic stream, but later was progressively restored. 
Only the exposure time significantly affected MC number in the skin $(p<0.001)$, and the dependent variables and their interaction had a significant effect on cell size. After $4 \mathrm{~d}$ of exposure, the number of skin mucocytes decreased in the 2 experimental groups, and cell numbers stayed constant over the exposure period (Fig. 2A). MC size increased progressively in the skin of fish exposed to non-acidic water, and the difference became significant after $7 \mathrm{~d}$ (Fig. 2B). A significant skin mucocyte hypertrophy was observed following the direct transfer into acidic water, and $\mathrm{MC}$ cell size returned to a basal level at the end of the $11 \mathrm{~d}$ experiment.

\section{MC of local fish}

In both epithelia, the number of cells was similar in the 2 wild fish populations (Figs. 3A \& 4A), but their sizes were larger in the fish from the acidic stream (Figs. 3B \& 4B).

\section{DISCUSSION}

The present investigation combines field experiments with transferred and wild fish populations. Moreover, it shows the concomitant responses, concerning mucus
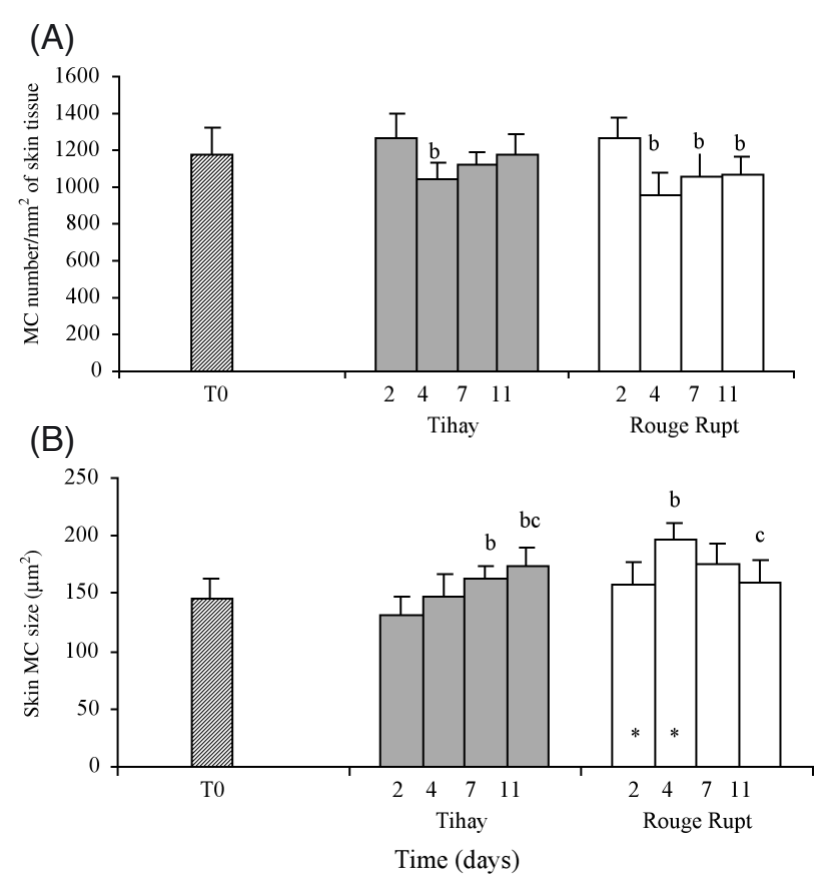

Fig. 2. Salmo trutta fario. (A) Mean number \pm SD of mucous cells (MC) per $\mathrm{mm}^{2}$ of skin tissue. (B) Mean size $\pm \mathrm{SD}$ of skin MC $\left(\mu \mathrm{m}^{2}\right)$. Trout were transferred into non-acidic water (Tihay) and into acidic water (Rouge Rupt). Data with letters and/or an asterisk are significantly different $(p<0.05)$ (see Fig. 1 legend for definitions) production, of 2 barrier epithelia in trout exposed to acidic water. The observed morphological changes may represent adaptive responses of the gill and skin to the acidic aquatic environment and its associated stressors, such as $\mathrm{Ca}$ depletion and high $\mathrm{Al}$ concentrations.

\section{Transferred fish}

The secretion of mucus by trout gill was stimulated by acidic water at the beginning of the transfer. In our study, this phenomena was reflected by a significant decline in the number and size of mucocytes. In addition, scanning electron microscopy revealed a thick layer of mucus occurring on the gill epithelium. Gill mucus hypersecretion corresponds to a non-specific response, and has been previously reported for fish under acidic conditions (Karlsson-Norrgren et al. 1986, McCahon et al. 1987, Jagoe \& Haines 1997), as well as for fish exposed to pollutants of a different nature (Mallatt 1985). In the mid-part of the exposure period, we observed cell hyperplasia associated with hypertrophy, which may have represented enhanced mucus production, again followed by MC depletion. These
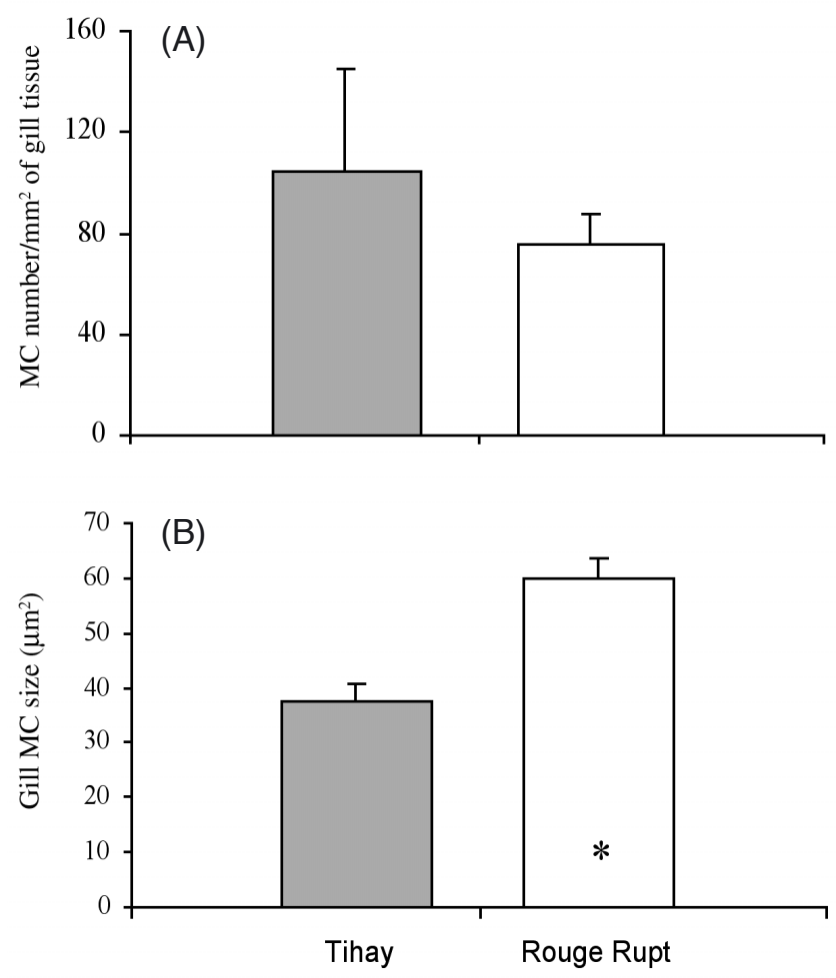

Fig. 3. Salmo trutta fario. (A) Mean number \pm SD of mucous cells (MC) per $\mathrm{mm}^{2}$ of gill tissue. (B) Mean size \pm SD of gill $\mathrm{MC}\left(\mu \mathrm{m}^{2}\right)$. Wild trout were caught in non-acidic water (Tihay) and in acidic water (Rouge Rupt). *: significant difference between the 2 streams $(p<0.05)$ 

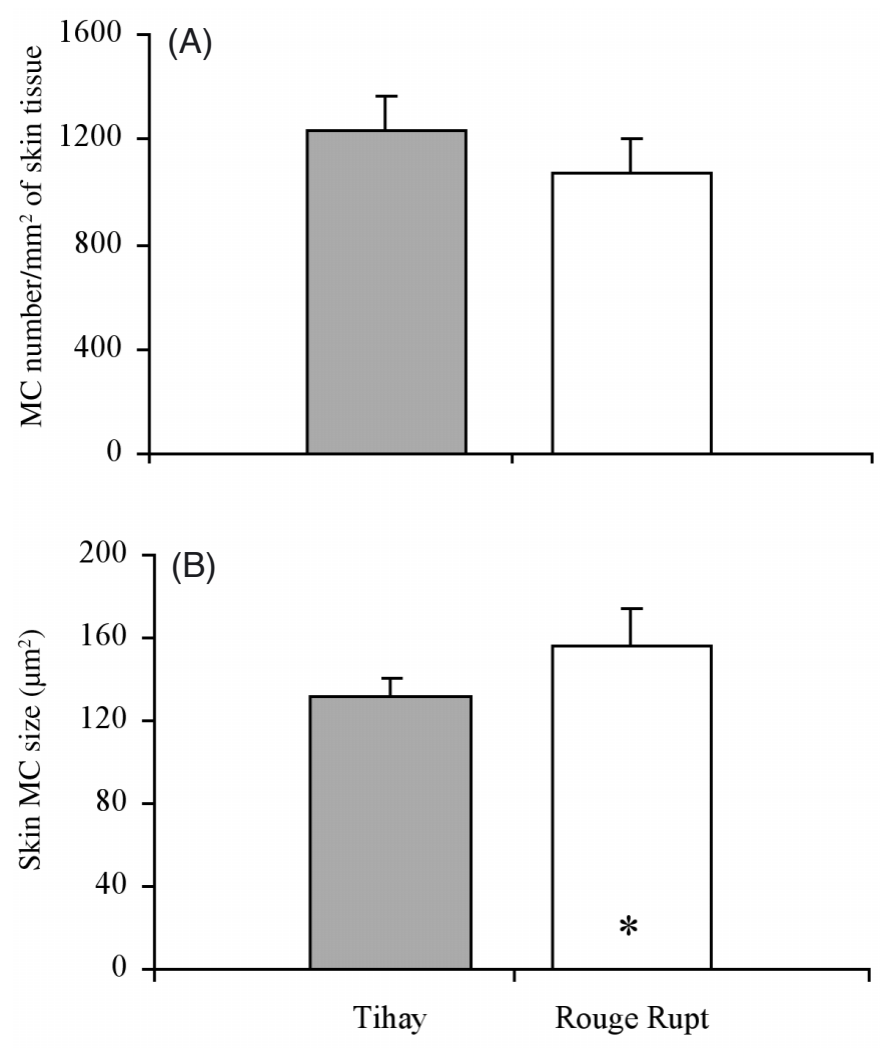

Fig. 4. Salmo trutta fario. (A) Mean number \pm SD of mucous cells (MC) per $\mathrm{mm}^{2}$ of skin tissue. (B) Mean size \pm SD of skin $\mathrm{MC}\left(\mu \mathrm{m}^{2}\right)$. Wild trout were caught in non-acidic water (Tihay) and in acidic water (Rouge Rupt). *: significant difference between the 2 streams $(p<0.05)$

results may indicate that the secretory potential of MC was apparently more exploited under acidic conditions, as observed by Iger \& Wendelaar Bonga (1994). Moreover, the variations in numerical density observed in acidic water may correspond to the turnover of mucocytes.

In the skin, numerical responses of MC were similar in the 2 streams. However, following direct transfer into the acidic stream, the observed cell hypertrophy may have been interrelated with a slightly enhanced mucification of the skin. The latter mucification has also been reported by others (Iger et al. 1994a, Witters et al. 1996), and may be involved in a protective function against the environmental acidic conditions. In the transferred fish, the discharge of mucus was earlier and higher on the gill epithelium, indicating that the gill was more sensitive than the skin to acidic water.

\section{Local fish population}

The wild trout of the acidic stream are the result of repeated annual restocking with embryonic/juvenile stages, and it is, thus, important to assess their health status. The presence of adults in the wild population suggested that genetic selection and/or development of acclimation and adaptive mechanisms to acidic conditions (Allin \& Wilson 2000) may have occurred. The responses of $\mathrm{MC}$ observed in wild trout (i.e. hypertrophy of gill and skin MC) could be involved in an acidic water adaptation of the fish.

The results of this histological study show that changes in mucocyte morphology may constitute a practical biomonitoring tool (Teh et al. 1997) to assess disturbances of aquatic ecosystems, such as water acidification. The present field experiment has suggested that fish transfer may lead to an early assessment of environmental contamination. In addition, the trials using wild populations have suggested the occurrence of adaptive mechanisms, information that might be of importance to river recovery programs.

Acknowledgements. We thank the Conseil Supérieur de la Pêche of the Vosges Department for conducting the electrofishing, and Guy Gehin (Office National des Forêts) for help in the field. The authors also wish to thank D. P. Molloy (New York State Museum) for his helpful comments on the manuscript.

\section{LITERATURE CITED}

Allin CJ, Wilson RW (2000) Effects of pre-acclimation to aluminium on the physiology and swimming behaviour of juvenile rainbow trout (Oncorhynchus mykiss) during a pulsed exposure. Aquat Toxicol 51:213-224

Berntssen MHG, Kroglund F, Rosseland BO, Wendelaar Bonga SE (1997) Responses of skin mucous cell to aluminum exposure at low $\mathrm{pH}$ in Atlantic salmon (Salmo salar) smolts. Can J Fish Aquat Sci 54:1039-1045

Claiborne JB (1998) Acid-base regulation. In: Evans DH (ed) The physiology of fishes. CRC Press, Boca Raton, FL, p 177-198

Goossenaerts C, Van Grieken R, Jacob W, Witters H, Vanderborght O (1988) A microanalytical study of the gills of aluminium-exposed rainbow trout (Salmo gairdneri). Int J Environ Anal Chem 34:227-237

Guérold F, Boudot JP, Merlet D, Rouiller J, Vein D, Jacquemin G (1997) Evaluation de l'état de santé des cours d'eau du département des Vosges. Convention No.14/956. Conseil Général des Vosges, Université de Metz

Guérold F, Boudot JP, Jacquemin G, Vein D, Merlet D, Rouiller J (2000) Macroinvertebrate community loss as a result of headwater stream acidification in the Vosges Mountains (N-E France). Biodiversity Conserv 9:767-783

Hesthagen T, Sevaldrud IH, Berger HM (1999) Assessment of damage to fish populations in Norwegian lakes due to acidification. Ambio 28:112-117

Iger Y, Wendelaar Bonga SE (1994) Cellular responses of the skin of carp (Cyprinus carpio) exposed to acidified water. Cell Tissue Res 275:481-492

Iger Y, Jenner HA, Wendelaar Bonga SE (1994a) Cellular responses in the skin of rainbow trout (Oncorhynchus mykiss) exposed to Rhine water. J Fish Biol 45:1119-1132 
Iger Y, Lock RAC, Jenner HA, Wendelaar Bonga SE (1994b) Cellular responses in the skin of carp (Cyprinus carpio) exposed to copper. Aquat Toxicol 29:49-64

Jagoe CH, Haines TA (1997) Changes in gill morphology of Atlantic salmon (Salmo salar) smolts due to addition of acid and aluminum to stream water. Environ Pollut 97: $137-146$

Karlsson-Norrgren L, Dickson W, Ljungberg O, Runn P (1986) Acid water and aluminium exposure: gill lesions and aluminium accumulation in farmed brown trout, Salmo trutta L. J Fish Dis 9:1-9

Laurent P (1984) Gill internal morphology. In: Hoar WS, Randall DJ (ed) Fish physiology. Academic Press, New York, p 73-184

Mallatt J (1985) Fish gill structural changes induced by toxicants and other irritants: a statistical review. Can J Fish Aquat Sci 42:630-648

McCahon CP, Pascoe D, Mc Kavanagh C (1987) Histochemical observation on salmonids Salmo salar L and Salmo trutta L and the ephemeropterans Baetis rhodani (Pict) and Ecdyonurus venosus (Fabr) following a simulated episode of acidity in an upland stream. Hydrobiologia 153:3-12

Olson KR (1996) Scanning electron microscopy of the fish gill. Fish Morphol 31-45

Editorial responsibility: Carl Schreck, Corvallis, Oregon, USA
Perry SF (1997) The chloride cell: structure and function in the gills of freshwater fishes. Annu Rev Physiol 59: 325-347

Probst A, Viville D, Fritz B, Ambroise B, Dambrine E (1992) Hydrochemical budgets of a small forested granitic catchment exposed to acid deposition: the Strengbach case study (Vosges Massif, France). Water Air Soil Pollut 62:337-347

Teh SJ, Adams SM, Hinton DE (1997) Histopathologic biomarkers in feral freshwater fish populations exposed to different types of contaminant stress. Aquat Toxicol 37: $51-70$

Verbost PM, Berntssen MHG, Kroglund F, Lydersen E, Witters HE, Rosseland BO, Salbu B, Wendelaar Bonga SE (1995) The toxic mixing zone of neutral and acidic river water: acute aluminium toxicity in Brown trout (Salmo trutta L). Water Air Soil Pollut 85:341-346

Witters HE, Puymbroeck SV, Stouthart AJHX, Bonga SEW (1996) Physicochemical changes of aluminium in mixing zones: mortality and physiological disturbances in Brown trout (Salmo trutta L). Environ Toxicol Chem 15:986-996

Zuchelkowski EM, Lantz RC, Hinton DE (1986) Skin mucous cell response to acid stress in male and female brown bullhead catfish, Ictalurus nebulosus (lesueur). Aquat Toxicol 8:139-148

Submitted: May 13, 2001; Accepted: July 29, 2003

Proofs received from author(s): September 8, 2003 